\title{
Investigation about Information Literacy Skills of Research Scholars
}

\author{
* Dr. Asaf Niwaz, Assistant Professor (Corresponding Author) \\ ** Dr. Kifayat Khan, Assistant Professor \\ *** Dr. Habib Elahi Sahibzada, Assistant Professor
}

\begin{abstract}
The study was a survey type with a quantitative focus of inquiry in which information literacy skills of post-graduate research scholars were analyzed. The sample of the study was taken from the University of Haripur. Data was collected through a questionnaire and it was analyzed in percentage form. It highlighted the level of information literacy skills of research scholars. The results may enable research supervisors and heads of departments to launch a practical training of research scholars during the course work of the M.Phil/Ph.D. It was suggested that a course of information literacy might be included at all levels of education to enable all students in general and research scholars in particular to use proper ways and means to excel in their academic life through the appropriate use of information literacy skills.
\end{abstract}

Keywords: Information Literacy, Research Scholars, Academic Performance, Postgraduates, Universities

\section{Introduction}

Education and technology are complement to each other and the knowledge of using technology is as important as the education itself. The world has been turned into a global village and technological developments have almost changed the concept of learning in a classroom. Physical presence is not necessary for learning anything but this situation is favorable to the learners of developed countries where communication facilities are in the access of everyone. Now learners have several learning avenues from which they can learn according to their pace of learning and at the appropriate time available to them. The learners can learn the best if they have knowledge and skills of using all available sources of learning. Learners need to have different learning skills including information literacy skills for optimal use of technology. Information literacy skills generally include the knowledge and skills of using different sources of gathering the most relevant information to solve the problems. In an educational setting, learners need to know how and from where relevant information can be collected. When learners reached the tertiary level of education where they have to do some research work to partially fulfillment the requirement of their degrees, the need for information literacy skills increases.

If a person can identify his required information needs, locate, evaluate and apply these in an appropriate way he is known as information literate. In this digitized world, internet users are facing new challenges and the information explosion results in creating anxiety among information users on how to locate the exact information out of a plethora, in the shortest time, and solve the problems appropriately and efficiently. Recent developments and fast growth of information lead the knowledge society which resultantly make information literacy a core skill for lifelong learning. It empowers individuals of all walks of life to seek, evaluate, use and create information for achieving their occupational, educational, personal, and social goals (Chanchinmawia \& Verma, 2017). The researcher could not find a single study on the topic at the national level although this particular area needs attention. Research scholars of universities do not necessarily possess the required level of information literacy skills and those who do not have information literacy skills lack behind in academic performance and cannot get maximum benefits of technological development in his/her surroundings. The present study was designed to examine the level of information literacy skills of research scholars at the postgraduate level in Pakistan. The research was focusing on seven pillars of information literacy given by SCONUL, 1999 to assess the level of IL skills of scholars.

* The University of Haripur Email: dr.ansatti75@ gmail.com

** The University of Haripur

*** Hazara University, Mansehra 


\section{Information literacy}

Knowledge is a power and it is true what one knows determines what he/she can do or cannot do. Based on knowledge one succeeds or fails in life, that's why we deliberately try to know what we think necessary to know. To learn something new requires appropriate information skills we become knowledgeable when we possess the necessary skills to know, locate, organize and decide appropriately. Mahadeva and Prasad (2016) defined IL as the ability to access, evaluate and use information from a variety of sources. It is considered as an ability, skill, and expertise, a capability and a competency that an individual possesses through which he can find the right information from the right sources. IL is basically to know information about information and the sources of information. It is not only a provision of information but a skilled navigator of a complex landscape. IL literate person is equipped with skills for handling information and he aware himself and his environment with latest information needs. IL comprises the competencies of recognizing information needs and to find out, evaluate, create, and apply the information within and social and cultural contexts. According to Chanchinmawia and Verma, (2017), IL is very important to the competitive advantage of human beings, enterprises both small and medium nature, for regions and nations. IL provides the key to quick access, effective use, and creation of content supporting economic activities, education, health and human-related services, and other aspects of contemporary societies. Through these competencies and services, the goals of the Millennium Declaration and World Summit on Information Society can be achieved. IL provides a base of lifelong learning common to all and interdisciplinary areas, to all learning environments, and also to all levels of education. IL enables individuals to locate the right information from authentic sources and he may extend his efforts for further investigations which leads him as a self-directed learner having more control over his learning. The institutions of higher learning should enable its learners as independent and self-directed learners (Kelvin, 2014). IL literate are well informed, continuously grow academically, and become lifelong and independent learners. CILIP, (2018) defines information literacy as "information literacy knows when and why you need information, where to find it, and how to evaluate, use and communicate it in an ethical manner." Joint and Wallis, (2015) pointed out the dynamic role of library and information association in enhancing the information literary. These authors also highlighted that many professional associations are working on making people aware of the IL. According to Stephen, Mutula et.al. (2006), information literacy through online learning mode of instruction can be improved easily as compared to the face-to-face mode of instruction because students preferred to have a blended learning approach instead of a singly learning approach. Digital media literacy consists of using a computer, social media, and the internet, and people who have a good level of media literacy are very much active in using social media for expressing their opinions appropriately (Zahid \& Shoeb, 2011). A study conducted in India revealed that research scholars pursuing their doctorate degrees have better information literacy skills as compared to those scholars studying at master of philosophy (Regha, 2011)). According to Vasudevan, (2012), postgraduate students and faculty working at the University of Kerels have a very low level of information literacy skills. These scholars and their faculty are unable to use the potential of online databases and indices for research and to bring positive output. Singh and Joshi (2013) found a significant difference in the performance of students of $1^{\text {st }}$ and $2^{\text {nd }}$-year students against basic standards of information literacy skills. In another study, Lata, and Sharma, (2013) proved that faculty members of different institutes have better information literacy skills as compared to their students. Similarly, another study conducted by Verma, and Rajiv (2013) highlighted the importance of the librarian role in the promotion of IL while a study conducted in Bangladesh IL competencies of students study Arts are limited (Islam \& Rahman (2014). Nicholas and Jake revealed the dynamic role of associations of library and information promotion worldwide while Chattopadhyay, (2017) stated that IL is the only way through which socio-economic development of disadvantaged community can be ensured and he suggested that IL programs should be organized through public libraries in regular intervals According to American Library Association (1989) an individual is said to be literate if he can recognize when information is needed and can locate, evaluate and use the information effectively. In the context of e-learning or online learning Julien, (2002) pointed out an information literate person should possess online searching skills which include the selection of relevant searching terminology, construction of logical strategy of searching information, and at the end ability to evaluate information appropriately. Association of College and Research Libraries observed the following abilities of an information 
literate individuals as highlighted by ILCSHE. (2006) which include abilities; to determine the extent of needed information, to access the required information effectively and efficiently, to critically evaluate the information and its sources, to incorporate the needed information into his/her knowledge base, to use information to accomplish the purpose, to understand economic, social and legal issues of using information and to use and access the information ethically and legally. Students need some level of information literacy skills to decide about academic matters and their daily lives. Julien, (2002) also identifies domains of information literacy skills and he classifies these as cognitive (thought), affective (attitude), and physical (operation). According to Todd, (2005), information literacy is an enabler of learning. Students need to engage actively in discussions and reflection about locating and using information to correct their concept and to confront variation in their own experience and the experiences of others (Bruce, Edwards \& Lupton, 2007). In the context of the $21^{\text {st }}$ century, Kuhlthau, (2007) is of the view that important for this century is to use the information for problem-solving instead of finding technology. The focus of information literacy is to enhance the abilities of students to develop and construct valid questions, reach valid consequences and share self emerging views successfully. Students also find out different ways and means of locating and using information. According to Streatfield, Allen and Wilson (2008) generally, information literacy is considered about libraries and resources, to locate and access required information, enable the student to construct and ask valid questions, use of internet surfing for gathering relevant information from relevant databases.

\section{Importance of Information Literacy}

Rapid technological development especially in the field of communication brought a significant change in the teaching and learning environment. According to Armitage, and O'Leary, (2003) the popularity of the internet led many academic staff members to use online resources in teaching and learning. This paradigm shift means both staff and students need to develop information-seeking behavior for quality, reliable, and representative online information (Walton \& Archer, 2004). The world of online information for students in their particular field of study is a complex one (Macdonald, Heap, \& Mason, 2001). The students reach higher education without having much knowledge about the tools they can use for accessing relevant and authentic information and the resources available to them (Rowley, 2000). He further elaborates that there are very limited studies that investigated the role of online resources in the learning process and there are many studies that focused on access and usage of information. The work of students in finding out and using information appropriately has been reported in researches of information studies. These research studies focused on specific needs such as in the field of health, particular cause, circumstances, and interest were explored as the most needed information. These do not focused on information behavior concerning educational theory, pedagogy, or learning process (Wilson, Ellis, Ford, \& Foster, 1999). According to McDowell, (2002) academic staff members are reluctant in demanding and encouraging any initiative of the student to use online resources in this era of the information economy. Oliver, (2003) having similar views and to him, there is pressure on academic staff to locate and use digital material in the teaching-learning process, and yet there is very little evidence that students persevere to and find and use digital information/material or resource in support of their studies. The trend or a need of using online resources ensures student-centered teaching (Thorpe, 2002). Information literacy not only necessary for our daily life but it is equally important for one's career life and educational pursuit. There is an abundance of knowledge available online of each subject and one who possesses information literacy skills can learn easily. According to Rockman, (2003), information literacy is not an issue of librarians only but it has utmost importance for all stakeholders of the education field like administrators, faculty, technologists, assessment coordinators, service providers, directors of faculty, personnel dealing with student's affairs, and career specialists. There are many sources of abundance of information like electronic, visual, sound, numeric, spatial, print, and image. There is also a challenge for faculty members to help students make a sound sense of this world of overload information everywhere (Boyer Commission, 1998). Students should be trained continually to formulate genuine questions and seek their answers in their entire academic life. Information literacy skills enable students to search, find, and effectively utilize the relevant information in the preparation of term papers and research projects/articles (Boyer Commission, 1998).

Research and information literacy skills are necessary for students in writing and critical thinking (Andrews, \& Patil, (2007); Grafstein, (2002). Information skills for students of the 
university are crucial and of utmost importance but there is little continuity in the expectations and assessment of these skills of students from schools level to tertiary level. Academic research is based on the individual's ability to locate and evaluate relevant information skills. Some of the students are proficient in developing approaches to using information and they sometimes take advantage of innovative technologies while many students do not possess such level of information skills. There are some important aspect of an academic life of the individual which affect his/her performance in research and these are; how researcher develop their research skills, the guidance they receive from their supervisors, the training opportunities available for them in the universities and the uptaking of such opportunities positively. In this paper, the researcher is trying to portray the number of and level of information literacy skills that research students need, to complete their thesis or research project.

\section{Seven Pillars of Information Literacy}

Information literacy is an umbrella under which many concepts like digital, visual, and media literacy, academic literacy, handling of information, information skills, data collection, and data management encompass. A researcher who is information literate would demonstrate skills of gathering, using, managing, synthesizing, creating, and ethically collecting data. According to NASPA (2004), information literacy has become a key attribute for everyone and its understanding is evident in the ways through which data is generally created and handled. How one modifying his learning attitudes, habits, and behaviors and how one uses it in research is also an important aspect of information literacy. The use of information, reflection, engagement, and active application of multiple contexts for constant search of meaning is understood as learning. Pillars of information literacy focused on different levels of literacy which a researcher needs to make wise decisions and progress in his academic life. Each of the pillars of information literacy, the researchers have to move from novice to expert in research that's why this model was chosen as the research lenses of this study. According to Bent, (2008), the level of expectations from the researcher from each of the pillars may be different in different contexts, and the progress will depend upon the experience and needed information. The pillars which are considered as lenses of this study, have skills and competencies as abilities of the research scholars and attitudes and behavior as an understanding of the research scholars, and this model was previously used as attributions of researchers in Higher education in the United Kingdom. Each of the pillars is further explained having several statements showing skills/competencies and attitudes/understandings but in this study, only a set of skills/competencies were taken and considered important to use to evaluate the existing level of information literacy skills of research scholars. Whenever a research scholar becomes more information literate he/she will demonstrate more attributes to move to the top of the pillar (Vitae, 2010). The pillars of the model of IL presented by SCONUL (1999) are described as under:

\section{Pillars of Information Literacy}

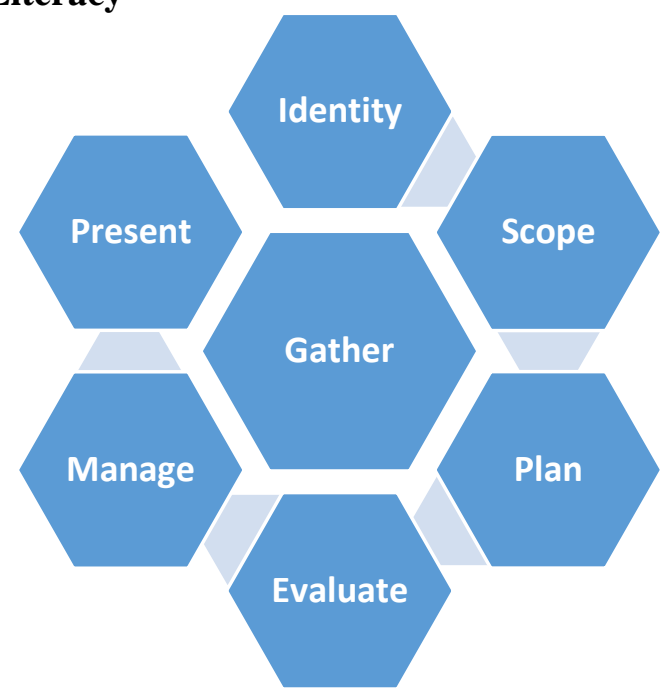

Pillar One: Identity

In the attitudes/understanding domain of this pillar, it is expected that the research scholar will understand that new knowledge is being produced continuously and there is a lot to learn; as an information literate, one has to develop learning and research habits in search of knowledge; through investigation and searching information new ideas and opportunities are easily created; a large scale 
of published and unpublished information/data is available; different disciplines of learning are placing more emphasis on types of information and data and; the need of information to research scholars largely depend on assign task, the discipline and at the stage of research.

In the domain of skills/competencies at this stage, it is expected that research scholar will be able to identify where in the subject he has lack of knowledge; identify research topic or question and define it in simple language; write clearly about current knowledge on the selected topic; recognize a need of information/data for the topic; write background information to strengthen the search; take research on his responsibility and; manage his routine to complete the research on time

\section{Pillar Two: Scope}

At this stage, the focus is to assess the current knowledge and identify the gap if any. It is expected that the research scholar will understand that available information; characteristics of different information sources e.g. books, journals, data banks, and their format; the process of dissemination of research output, the publication of result with a clear understanding of its importance of sharing with others; issues of accessibility (free/subscribe, license restrictions, electronic or print); what services are available and how to access these like libraries, people, organizations. In the skills domain it is expected that research scholar would be able to self-knowledge what he knows and what he does not know; identify the best information he/she needs to complete the task; use different available tools of searching information; apply different methods of data collection; identify different formats (print, digital, multimedia) to provide information and; show the ability to use newly available tools of research

\section{Pillar Three: Plan}

At stage three, a research scholar will construct strategies for locating information and data, and it is expected that he/she understands that the nature of research, discuss with other, internet browsing, data mining to find information; difference among search tools like bibliographic databases, a subject gateway, search engines and familiarity with a range of different retrieval tools with advantages /limitations; complex search strategies make difference in getting in-depth information; the need to use different search approaches for new questions instead of using anyone; match the data collection techniques with circumstances; revise keywords to get more and more information and; value the controlled vocabulary and taxonomies in searching information

$\mathrm{He} /$ she will be able to develop research question clearly and inappropriate language; articulate search strategy using keyword, concepts, define and set limits; using and selecting most appropriate search tool as data collection technique; identify the controlled vocabularies and taxonomies for searching information, and use and apply appropriate search techniques and specialist search tools as well

\section{Pillar Fourth: Gather}

The research scholar will locate and access information/data and understand how information/data collected from digital or print sources is organized; the ways libraries acquire and provide access to the resources of authentic information; how collaborative tools of digital technologies are used to create and share information; what issues are involved in data collection; how to cite the information correctly; the usage of abstracts and need to keep oneself up to date with new information; the relevance of open access resources and risk involved in working in virtual environments; the importance of acknowledging and assessing search results

In the skills/competencies domain of this stage, it is hoped that the research scholar will be able to use different tools and resources to get information; construct complex searches for data collection from print and digital resources; translate search strategy to work in different resources; redefine searching strategies which are based on previous results; sorting and manipulating results; download full-text material of print and digital resources; use of research techniques for the collection of data and; keep oneself up to date with new information through email alerts and RSS feeds, etc.

\section{Pillar five: Evaluate}

The research scholars are expected to compare and evaluate information/data and review of the research process. It is expected that the research scholar will understand that how different information/data landscape of relevant field fits in current research; the authenticity of sources of information/data concerning the issues of quality, accuracy, relevance, bias, reputation and credibility; the importance of consistency in the data collection process of research; the evaluation criteria of 
results of a research activity and dissemination of result through a peer review process, publication, etc.

In this pillar, the research scholars are expected to have these skills/competencies given below. They will demonstrate the ability to distinguish among different types of information resources like web pages, scholarly, professional, and reputed journals; setting appropriate criteria from a selection of different material on the topic; access the accuracy, bias, quality, credibility, and reputation of information resources; critical revision of available information to identify key points and arguments; appraising and evaluating own findings and those of others in discussions; proper citation of the information resources and; editing and reviewing the research work of the colleagues.

\section{Pillar Sixth: Manage}

This stage of information literacy mainly deals with an understanding of a research scholar to the organization of information professionally and ethically. It is hoped that the information literate of this stage will understand self-responsibility of acting with professional integrity and honesty throughout the research activity especially in the issues of copyright, plagiarism, and IP; adaptation of appropriate information handling and methods of curation; how to play a role to cooperate with others in seeking and managing information; keep a record of used search strategies, resources, and data found, etc., the relevance of the information to research work, need to curate and archives research data ethically; the help that one can avail from data managers or librarians;

The research scholars will be able to use bibliographic software to manage information/data; apply appropriate or suggested referencing style of citation and create formatted bibliographies; appropriately handle the issues of data protection, copyright, plagiarism, or other intellectual property as rights of others researchers and participants; meeting and setting academic standards of conduct; identification of data curation to ensure ethical storage of data and its re-usage in other research activities and; use of data management software and techniques to manage and curate data as an available resource for others

\section{Pillar Seventh: Present}

At this stage, research scholars are supposed to apply gained knowledge by presenting results of research, synthesize new and old information/data to create new knowledge, and disseminate it in a variety of ways. The research scholars are hoped to understand the difference between summarizing and synthesizing information; presentation of information to different communities require different writing and presenting styles; share and curate information/data on personal responsibility; dissemination of information and knowledge on subject to the community and the wider world; how researcher peer review, evaluate and disseminate research outputs; academic exploitation and publication of research outputs; properly citation of resources and; active researcher in the creation of knowledge and publishing through blogs and wikis, etc.

In the context of researchers' skills /competencies, they are expected to be able to use information/data to address the research question of study/project; make summaries of reports and documents in writing and verbally; analyze and presentation data appropriately; integrate new findings with existing one and highlight connections between own data and literature; use different information sources to synthesis and appraise new and complex data; share and communicate new knowledge in different ways like articles, conference papers, literature reviews, scientific reports, poster, visually or Web 2.0; use open access and traditional sources of publishing and; develop and maintain the scholarly community by sharing information as discussion lists, social networking or blogs, etc.

\section{Methods}

This study was descriptive and a survey design was used. The population comprised of all research scholars of departments of Islamic and religious studies, Forestry and Wildlife Management, Environmental science, Agricultural Sciences and Education. All research scholars were considered as participants of the study. Views of the scholars who had completed their course work and whose synopses had been approved for final research were included. A Questionnaire was used to collect the data from research scholars of different departments. The questionnaire was constructed in the light of knowledge and skills described under each of the pillars of IL. Very simple statements covering each pillar were included and research scholars were requested to reflect according to their level of competency ranging from very poor, poor, beginner/not confident, intermediate, and expert. Before the collection of data, consent was sorted from the head of the departments as well as from research 
scholars. At the given date and time, the head of departments had requested their research scholars to come and in most of the cases, the research scholars reached in the evening after finishing their daytime activities. Most of the research scholars were on jobs and in the evening they were feeling relaxed. The data collection took almost a month time and it was collected from single to group of research scholars in a single setting. The data were analyzed through frequency distribution and presented in percentages. Percentages indicate the level of IL skills of the scholars.

\section{Results and Conclusions}

Table 1: Skills and competencies of Identification

\begin{tabular}{lcllll}
\hline \multicolumn{1}{c}{ Statements } & Expert & Int. med & Beginner & Poor & Very Poor \\
\hline $\begin{array}{l}\text { I can identify a lack of knowledge in my } \\
\text { subject area }\end{array}$ & $23(62 \%)$ & $5(13.5 \%)$ & $6(16.2 \%)$ & $1(2.7 \%)$ & $2(5.4 \%)$ \\
$\begin{array}{l}\text { I can identify a research topic/question } \\
\text { and define it using simple terminology }\end{array}$ & $11(29.7 \%)$ & $8(21.6 \%)$ & $9(24.3 \%)$ & $5(13.5 \%)$ & $4(10.8 \%)$ \\
$\begin{array}{l}\text { I can use background information to } \\
\text { underpin the research topic }\end{array}$ & $7(18.9 \%)$ & $11(29.7 \%)$ & $10(27 \%)$ & $5(13.5 \%)$ & $4(10.8 \%)$ \\
$\begin{array}{l}\text { I can take personal responsibility for a } \\
\text { research thesis }\end{array}$ & $24(64.8 \%)$ & $12(32.4 \%)$ & $1(2.7 \%)$ & 0 & 0 \\
$\begin{array}{l}\text { I can manage my own time effectively to } \\
\text { complete a research thesis }\end{array}$ & $11(29.7 \%)$ & $10(27 \%)$ & $9(24.3 \%)$ & $6(16.2 \%)$ & $1(2.7 \%)$ \\
\hline
\end{tabular}

Table 1 indicates that more than sixty percent of research scholars can identify their weak area in subject matter knowledge while nearly one fourth were even think about themselves as weak and poor in identifying their weaknesses. Similarly about half of the scholars think about themselves as above basic level and able to identify a research topic/question and they can define these in simple terminology. More than half of the respondents believed that they are not confident and poor in using background information to strengthen their research topic while most of the respondents opined that they took the research on their responsibility and they can easily manage their own time to complete the research.

Table 2: Skills and competencies of Scope

\begin{tabular}{|c|c|c|c|c|c|}
\hline Statements & Expert & Int. med & Beginner & Poor & Very Poor \\
\hline $\begin{array}{l}\text { I can identify which types of information } \\
\text { (e.g. data, people, videos, published } \\
\text { information) will best meet my need }\end{array}$ & $8(21.6 \%)$ & $11(29.7 \%)$ & $9(24.3 \%)$ & $8(21.6 \%)$ & $1(2.7 \%)$ \\
\hline $\begin{array}{l}\text { I can identify the available search tools, } \\
\text { such as general and subject-specific } \\
\text { resources at different levels in research }\end{array}$ & $6(16.2 \%)$ & $9(24.3 \%)$ & $13(35 \%)$ & $7(18.9 \%)$ & $2(5.4 \%)$ \\
\hline I know the different data collection methods & $5(13.5 \%)$ & $6(16.2 \%)$ & $9(24.3 \%)$ & $9(24.3 \%)$ & $8(21.6 \%)$ \\
\hline $\begin{array}{l}\text { I identify different formats in which } \\
\text { information may be provided ( e.g. print, } \\
\text { digital, multimedia) }\end{array}$ & $10(27 \%)$ & $9(24.3 \%)$ & $8(21.6 \%)$ & $6(16.2 \%)$ & $4(10.8 \%)$ \\
\hline $\begin{array}{l}\text { I demonstrate the ability to use new tools as } \\
\text { they become available }\end{array}$ & $5(13.5 \%)$ & $8(21.6 \%)$ & $9(24.3 \%)$ & $9(24.3 \%)$ & $6(16.2 \%)$ \\
\hline
\end{tabular}

Analysis of table 2 showed that about half of respondents can identify which type of data or information suited best their needs while the other slot of half percent claimed that they cannot do so. Similarly, most of the respondents were of the view that they were not able to identify different search tools, data collection methods and they were not able to use new tools of research while most of the respondents thought that they identified different formats of information like print or digital or multimedia.

Table 3: Skills and competencies of Planning

\begin{tabular}{llllll}
\hline Statements & Expert & Int. med & Beginner & Poor & Very Poor \\
\hline $\begin{array}{l}\text { I develop research questions clearly and } \\
\text { inappropriate language }\end{array}$ & $4(10.8 \%)$ & $9(24.3 \%)$ & $8(21.6 \%)$ & $8(21.6 \%)$ & $8(21.6 \%)$ \\
$\begin{array}{l}\text { I select the most appropriate search tools } \\
\text { (people, search engines, databases, etc.) and } \\
\text { data collection techniques }\end{array}$ & $5(13.5 \%)$ & $7(18.9 \%)$ & $9(24.3 \%)$ & $9(24.3 \%)$ & $7(18.9 \%)$ \\
$\begin{array}{l}\text { I identify controlled vocabularies and } \\
\text { taxonomies to aid in searching the relevant } \\
\text { information in a different context }\end{array}$ & $5(13.5 \%)$ & $9(24.3 \%)$ & $8(21.6 \%)$ & $6(16.2 \%)$ & $9(24.3 \%)$ \\
\hline
\end{tabular}


At this stage of research, most of the research scholars perceived themselves as they were not able to develop research questions appropriately, they were not able to select the best searching tools and data collection techniques and they were not able to identify controlled vocabularies and taxonomies to search the most relevant information in different contexts.

\section{Table 4: Skills and competencies of Gathering}

\begin{tabular}{|c|c|c|c|c|c|}
\hline Statements & Expert & Int. med & Beginner & Poor & Very Poor \\
\hline $\begin{array}{l}\text { I Use a range of different retrieval tools } \\
\text { and resources effectively (e.g. databases, } \\
\text { digital resources, other libraries) }\end{array}$ & $7(18.9 \%)$ & $10(27 \%)$ & $9(24.3 \%)$ & $8(21.6 \%)$ & $3(8 \%)$ \\
\hline $\begin{array}{l}\text { I can redefine a search strategy based on } \\
\text { the previous result }\end{array}$ & $5(13.5 \%)$ & $9(24.3 \%)$ & $9(24.3 \%)$ & $8(21.6 \%)$ & $6(16.2 \%)$ \\
\hline I sort and manipulate results & $8(21.6 \%)$ & $7(18.9 \%)$ & $9(24.3 \%)$ & $9(24.3 \%)$ & $4(10.8 \%)$ \\
\hline $\begin{array}{l}\text { I can access full-text information, both } \\
\text { print and digital, read and download } \\
\text { online material and data }\end{array}$ & $9(24.3 \%)$ & $12(32.4 \%)$ & $8(21.6 \%)$ & $6(16.2 \%)$ & $2(5.4 \%)$ \\
\hline $\begin{array}{l}\text { I keep myself up to date with new } \\
\text { information (e.g. email alerts, RSS feeds) }\end{array}$ & $8(21.6 \%)$ & $10(27 \%)$ & $9(24.3 \%)$ & $7(18.9 \%)$ & $3(8 \%)$ \\
\hline $\begin{array}{l}\text { I Use online and printed material and can } \\
\text { find personal or expert help }\end{array}$ & $9(24.3 \%)$ & $7(18.9 \%)$ & $9(24.3 \%)$ & $8(21.6 \%)$ & $4(10.8 \%)$ \\
\hline
\end{tabular}

Table 4 showed that most of the respondents were perceived themselves as low confident and poor in the skills of using a range of retrieval tools/resources of data, redefining search strategies, sorting and manipulating results, and in the use of online and printed to get more help from others. A very small number of research scholars opined that they have the aforementioned abilities. In the skills of accessing full-text information, downloading data, keeping them up to date with new information through email alerts or RSS feeds, they felt confidents.

Table 5: Skills and competencies of Evaluation

\begin{tabular}{|c|c|c|c|c|c|}
\hline Statements & Expert & Int. med & Beginner & Poor & Very Poor \\
\hline $\begin{array}{l}\text { I can distinguish among different information } \\
\text { resources (e.g. web pages, scholarly, } \\
\text { professional, \& reputed journals) }\end{array}$ & $5(13.5 \%)$ & $8(21.6 \%)$ & $9(24.3 \%)$ & $8(21.6 \%)$ & $7(18.9 \%)$ \\
\hline $\begin{array}{l}\text { I choose a range of materials on topics, using } \\
\text { appropriate criteria }\end{array}$ & $4(10.8 \%)$ & $9(24.3 \%)$ & $7(18.9 \%)$ & $8(21.6 \%)$ & $9(24.3 \%)$ \\
\hline $\begin{array}{l}\text { I can assess the quality, accuracy, relevance, } \\
\text { bias, reputation, and credibility of the } \\
\text { information resources found }\end{array}$ & $3(8 \%)$ & $9(24.3 \%)$ & $8(21.6 \%)$ & $7(18.9 \%)$ & $10(27 \%)$ \\
\hline $\begin{array}{l}\text { I read critically to identifying key points and } \\
\text { arguments }\end{array}$ & $8(21.6 \%)$ & $9(24.3 \%)$ & $8(21.6 \%)$ & $7(18.9 \%)$ & $5(13.5 \%)$ \\
\hline $\begin{array}{l}\text { I critically appraise and evaluate my findings } \\
\text { and those of others in discussion }\end{array}$ & $8(21.6 \%)$ & $9(24.3 \%)$ & $7(18.9 \%)$ & $8(21.6 \%)$ & $5(13.5 \%)$ \\
\hline I can edit/ peer review the work of colleagues & $5(13.5 \%)$ & $7(18.9 \%)$ & $9(24.3 \%)$ & $9(24.3 \%)$ & $7(18.9 \%)$ \\
\hline
\end{tabular}

Table 5 revealed that most of the research scholars did not possess the skills of distinguishing different information sources, criterion searching of range of materials, assessing the quality, credibility, and accuracy of found material, reading critically to find key points/ideas, and discussing the main finding concerning findings of others researches, and editing/peer-reviewing the work of colleagues.

\section{Table 6: Skills and competencies of Managing}

\begin{tabular}{lccccc}
\hline \multicolumn{1}{c}{ Statements } & Expert & Int. med & Beginner & Poor & Very Poor \\
\hline $\begin{array}{l}\text { I can cite printed and electronic sources } \\
\text { using suitable and suggested referencing } \\
\text { styles }\end{array}$ & $7(18.9 \%)$ & $9(24.3 \%)$ & $10(27 \%)$ & $8(21.6 \%)$ & $3(8 \%)$ \\
$\begin{array}{l}\text { I can create formatted bibliographies } \\
\text { appropriately }\end{array}$ & $5(13.5 \%)$ & $9(24.3 \%)$ & $9(24.3 \%)$ & $8(21.6 \%)$ & $6(16.2 \%)$ \\
$\begin{array}{l}\text { I can demonstrate awareness of issues } \\
\text { relating to the rights of other researchers }\end{array}$ & $4(10.8 \%)$ & $8(21.6 \%)$ & $10(27 \%)$ & $9(24.3 \%)$ & $6(16.2 \%)$ \\
$\begin{array}{l}\text { and research participants, including ethics, } \\
\text { data protection, copyright, plagiarism, and } \\
\text { any other intellectual property issues }\end{array}$ & & & & & \\
$\begin{array}{l}\text { I can set and meet standards of conduct for } \\
\text { nand }\end{array}$ & $4(10.8 \%)$ & $9(24.3 \%)$ & $9(24.3 \%)$ & $8(21.6 \%)$ & $7(18.9 \%)$
\end{tabular}


academic integrity

$\begin{array}{llllll}\text { I can use appropriate data management } \quad 3(8 \%) & 8(21.6 \%) & 7(18.9 \%) & 9(24.3 \%) & 10(27 \%)\end{array}$ software and techniques to manage and curate research data

Table 6 identified that research scholars were lacking in the skills of citing and referencing, creating bibliographies, adopting research ethics, incorporating copyright issues, avoid plagiarism, and other intellectual property issues. A large number of research scholars also claimed that they were not able to set and meet academic standards, use data management software to manage and curate research data.

\section{Table 7: Skills and competencies of Presentation}

\begin{tabular}{llllll}
\hline Statements & Expert & Int. med & Beginner & Poor & Very Poo \\
\hline $\begin{array}{l}\text { I can use the information and data to address } \\
\text { the research question }\end{array}$ & $6(16.2 \%)$ & $9(24.3 \%)$ & $8(21.6 \%)$ & $9(24.3 \%)$ & $5(13.5 \%)$ \\
$\begin{array}{l}\text { I can summarize documents and reports } \\
\text { verbally and in writing very well }\end{array}$ & $4(10.8 \%)$ & $9(24.3 \%)$ & $10(27 \%)$ & $8(21.6 \%)$ & $6(16.2 \%)$ \\
$\begin{array}{l}\text { I can analyze and present data appropriately } \\
\text { I can incorporate new research findings into } \\
\text { the context of existing knowledge }\end{array}$ & $7(18.9 \%)$ & $9(24.3 \%)$ & $9(24.3 \%)$ & $8(21.6 \%)$ & $4(10.8 \%)$ \\
$\begin{array}{l}\text { I can integrate connections between sections } \\
\text { of own data and the literature }\end{array}$ & $5(13.5 \%)$ & $8(21.6 \%)$ & $7(18.9 \%)$ & $9(24.3 \%)$ & $8(21.6 \%)$ \\
$\begin{array}{l}\text { I can synthesise and appraise new and } \\
\text { complex information from different sources }\end{array}$ & $4(10.8 \%)$ & $7(18.9 \%)$ & $8(21.6 \%)$ & $9(24.3 \%)$ & $9(24.3 \%)$ \\
$\begin{array}{l}\text { I can communicate effectively using } \\
\text { appropriate writing styles in a variety of } \\
\text { formats (abstract, literature review, journal } \\
\text { article, conference paper) }\end{array}$ & $3(8 \%)$ & $7(18.9 \%)$ & $6(16.2 \%)$ & $10(27 \%)$ & $11(29.7 \%)$ \\
$\begin{array}{l}\text { I can select appropriate publications and } \\
\text { dissemination outlets in which to publish } \\
\text { research findings and data }\end{array}$ & $4(10.8 \%)$ & $6(16.2 \%)$ & $8(21.6 \%)$ & $10(27 \%)$ & $9(24.3 \%)$ \\
\hline
\end{tabular}

Table 7 indicated that researcher scholars had a lack of confidence and poor in the skills of using information to address research questions, summarizing different documents, analyzing and presenting results. They were also not confident and have a poor understanding of the skills of integrating research finding to existing knowledge, synthesizing and appraising information, communicating with different writing styles, and selected appropriate publications to disseminate knowledge effectively.

\section{Recommendations}

I would like to conclude my research with the observations made by research supervisors of concerned departments. An introductory guide on information literacy skills may be developed in the university with the involvement of experts from the Information technology department to consult on regular basis throughout the course work of M.Phil/Ph.D level. Most of the assignments given in each subject may focus on the use of maximum information literacy skills in its completion.

Staff of the library may be trained first to facilitate research scholars in their efforts to collect updated knowledge and information data. The library staff may be made expert in information literacy skills so that maximum students may get help easily, efficiently, effectively, and easily at the spot. Apart from staff of libraries, faculty members involved in supervision may be made information literate on a compulsory basis to facilitate the scholars on an individual and collective basis in the office or classrooms.

As a whole, only a few research scholars possess the information literacy skills while other despite having very key positions in the society or their relevant departments (e.g., district officers, agriculturists, admin officers, foresters, entrepreneurs, subject specialists, principals, and senior teachers) are professionally in dire need of information skills to progress and improve their services. After getting enrolled in the departments for higher studies, generally, they rely on the information literacy skills of their subordinates who do not know what to do in the completion of assignments or research-based tasks. These officials in most of the cases fail to complete their studies and if they somehow manage, they are not able to contribute positively as an employee. 
Training of research supervisors in information literacy is as important as research scholars may have. For smooth working of supervisors and their research scholars, both need equal and extensive literacy skills training of at least one month covering all key areas.

Academic staff must assign all assignments and classroom presentations to the research scholars which may require efficient use of information literacy skills.

Throughout the course work, research scholars may be encouraged to use and learn computer literacy skills necessary to keep them up to date with current knowledge and information.

Head of the departments may encourage their faculty members to apply active pedagogical practices such as problem-solving, project method and inquiry based teaching, etc which are in support of and well supported by effective use of information literacy skills. The active involvement of research scholars in the teaching-learning process may be encouraged also. In the present time when natural disasters like Covid-19 spread across the globe make it necessary for everyone to use technology to meet their daily needs. It is of utmost importance for researchers and teachers to use online teaching-learning techniques to get updated and the latest knowledge and transmit it to their students effectively. The present-day situations truly categorized illiterate to those who do not have good skills of IL. There is a need to spread awareness among common people apart from students to have IL for their continuous learning and to become self-directed learners as well as lifelong learners.

\section{References}

American Library Association, (1989). Presidential Committee on Information Literacy Final Report. Chicago: ALA,

Andrews, T., \& Patil, R. (2007). Information literacy for first-year students: An embedded curriculum approach. European Journal of Engineering Education, 32(3), 253-259

Armitage, S. \& O'Leary, R. (2003). A guide for learning technologists, e-learning series No 4 (York, LTSN Generic Centre). Available online at: http://www.ltsn.ac.uk/

Bent, M, (2008). Perceptions of Information Literacy in the transition to higher education. National Teaching Fellowship Report, Newcastle University.

Boyer Commission on Educating Undergraduates in the Research University Reinventing Undergraduate Education (1998): A Blue Print for America's Research Universities

Bruce, C.S., Edwards, S. \& Lupton, M. (2007). Six frames for information literacy education: a conceptual framework for interpreting the relationships between theory and practice. In S. Andretta (Ed.), Change and challenge: information literacy for the 21st century (pp. 37-57). Adelaide: Auslib Press.

Chanchinmawia, F. \& Verma, M. K. (2017). Significance of Information Literacy in Digital Environment among Academic Community and Role of Library Professionals, inEd.Bansal, Vaibhav et.al, Conjugative management, library information science, social science and technology for virtual world, New Delhi, 117-122.

Chattopadhyay, T. (2017). Information literacy through community development programs of public libraries: A proposed model for Odisha state. The Journal of UGC - HRDC Nainital, $11(2) ; 135-143$.

CILIP, (2018). Information-literacy-group, available at:http://www.cilip.org.uk/about/special-interestgroups/ (Accessed 16 January 2018). 5.

Grafstein, A. (2002). A discipline-based approach to information literacy. The Journal of Academic Librarianship, 28(4), 197-204.

Information Literacy Competency Standards for Higher Education (ILCSHE. (2006). American Library Association

Islam, Md. M. \& Rahman, Md. A . (2014). Assessing information literacy competency of arts faculty students at the University of Dhaka, Library Philosophy and Practice, available at: http://digitalcommons.unl.edu/libphilprac/1110(accessed on 19 January 2018).

Joint, N. \& Wallis, J. (2015). Information literacy and the role of national library and information associations, Library Review, 54 (4); 213-217.

Julien, H. (2002).Use of information. Encyclopedia of Communication and Information. USA: Macmillan Reference. p.1051-1056.

Kelvin, M. K., (2014). Authentic engagement: Assessing the effects of authenticity on student engagement and information literacy in academic library instruction. Reference Services Review, 42 (2); 229-245. 
Kuhlthau, C.C. (2007). From Information to meaning: confronting the challenges of the $21^{\text {st }}$ Century. Keynote paper presented at Information: interactions and impact Conference, Aberdeen.

Lata, S. \& Sharma, S. (2013).Information literacy among faculty and students of postgraduate institute of medical education and research, Chandigarh and Pt. B. D. Sharma University of health sciences, Rohtak. International Journal of Information Dissemination and Technology, 3(4); 244-248.

Macdonald, J., Heap, N. \& Mason, R. (2001). 'Have I learned it?' Evaluating skills for resource-based study using electronic resources, British Journal of Educational Technology, 32(4), 419-433.

Mahadeva, S. \& Prasad M. (2016). Information search and information literacy skills of faculty of polytechnic colleges in Karnataka in utilizing information resources: an analytical study, available at: http://hdl. handle.net/10603/134584(Accessed on 4th February 2018).

McDowell, L. (2002).Electronic information resources in undergraduate education: an exploratory study of opportunities for student learning and independence, British Journal of Educational Technology, 33(3), 255-266.

NASPA (2004): National Association of Student Personnel Administrators Learning Reconsidered: A campus-wide focus on the student experience. American College Personnel Association.

Oliver, M. (2003). Rethinking the reuse of electronic resources: contexts, power and information literacy, Journal of Interactive Media in Education, 1.

Regha, V. S. (2011).A study on information literacy competency of research scholars of the University of Madras, available at: http://shodhganga.Inflibnet.ac.in/handle/10603/40624 (accessed on 3rd February 2018).

Rockman, Ilene F, (2003).Library Instruction to EOP Students: A Case Study. Bethesda, Roth, Lorie. "Educating the Cut-and-Paste Generation. Library Journal, Nov. 1.

Rowley, J. (2000).User behavior monitoring and evaluation framework (Bristol, JISC).

SCONUL (1999). Advisory Committee on Information Literacy Information skills in higher education: a SCONUL position paper. Prepared by the Information Skills Task Force, on behalf of SCONUL.

Singh, D. \& Joshi, M. K. (2013). Information literacy competency of postgraduate students at Haryana Agricultural University and impact of instruction initiatives: A pilot survey. Reference Services Review, 41(30); 453-473.

Stephen, Mutula et.al. (2006). Design and implementation of an online information literacy module: Experience of the Department of Library and Information Studies, University of Botswana. Online Information Review, 30(2); 168-187.

Streatfield, D.R., Allen, D. \& Wilson, T.D. (2008). Mind the skills gap: information handling training for researchers. London: The Research Information Network.

Thorpe, M. 2002). (From independent learning to collaborative learning: new communities of practice in open, distance and distributed learning, in: M. R. Lea \& K. Nicoll (Eds) Distributed learning: social and cultural approaches to practice (London, Routledge Falmer).

Todd, R. (2005). Information literacy and inquiry learning: the role of the library and what it achieves. Keynote paper presented at the School Library Association Annual Conference, Surrey.

Vasudevan T. M. (2012). (Information literacy of research scholars of Universities in Kerala. available at: http://hdl.handle.net/10603/92875 (accessed on 4 February 2018).

Verma, M. K. \& Rajiv, P. (2013). Information Literacy in Academic Environment: An Indian Perspective. In -Reddy, E . Rama et.al, Information management today and tomorrow, Today and Tomorrow publishers, New Delhi; 589594.

Vitae, (2010). The Researcher Development Framework,

Walton, M. \& Archer, A. (2004). The Web and information literacy: scaffolding the use of web sources in a project-based curriculum, British Journal of Educational Technology, 35(2), 173-186.

Wilson, T. D., Ellis, D., Ford, N. \& Foster, A. (1999). Uncertainty in information seeking: final report to the British Library Research and Innovation Centre.

Zahid Hossain \& Shoeb Md. (2011). Information literacy competency of freshman business students of a private university in Bangladesh, Library Review. 60(9); 762772. 